\title{
General Intomology/Intomologia Geral Vibration of the plant substrate generated by workers' stridulation during fungus garden cultivation in Atta laevigata (Smith) (Hymenoptera: Formicidae)
}

\author{
Amanda Aparecida Carlos ${ }^{\varpi}$, Eduardo Arrivabene Diniz, Sandra Verza da Silva \& Odair Correa Bueno
}

Universidade Estadual Paulista Júlio de Mesquita Filho (UNESP) - Campus Rio Claro, Centro de Estudos de Insetos Sociais.

EntomoBrasilis 11 (2): $107-112$ (2018)

\begin{abstract}
The communication between leaf-cutting ants occurs through chemical interactions and sound, which are important processes in the complex social system of these organisms. Studies have focused on the characterization and importance of stridulation and vibration of the substrate for ants in general. However, for leaf-cutting ant species, little information is available about the characterization and the function of vibration of the substrate during preparation and incorporation of plant material into the symbiotic fungus by workers. Therefore, the objective of the present study was to describe the vibration in Eucalyptus leaves generated by the stridulation of Atta laevigata (Smith) workers during processing and incorporation of the plant material into the symbiotic fungus, and to discuss its possible function. Vibrational signals were recorded with a laser vibrometer. The amplitudes of the emitted signals varied according to the behaviors performed, that is, each behavior showed a characteristic amplitude. Thus, the vibration in the leaves probably can aid in the efficiency of these ants during the processing of the vegetal material for the incorporation in its symbiont.
\end{abstract}

Keywords: Behaviour; Bioacoustics; Eucalyptus sp.; Leaf cutter ants.

\section{Vibração do substrato vegetal gerada pela estridulação de operárias durante o cultivo do fungo em Atta laevigata (Smith) (Hymenoptera: Formicidae)}

Resumo. A comunicação entre as formigas cortadeiras ocorre por meio da interação química e do som, processos importantes no complexo sistema social destes organismos. Existem vários estudos enfocando a caraterização e a importância da estridulação e vibração do substrato para as formigas em geral. Contudo, pouco se tem descrito para as espécies de formigas cortadeiras sobre a caracterização e função da vibração do substrato durante o preparo e a incorporação do material vegetal pelas operárias no fungo simbionte. Assim, o presente trabalho descreveu a vibração nas folhas de Eucalyptus sp. gerada pela estridulação das operárias de Atta laevigata (Smith) durante o processamento e incorporação destas folhas no fungo simbionte, além de interpretar sua possível função. Os sinais vibratórios foram gravados com um vibrômetro a laser. As amplitudes dos sinais emitidos variaram conforme os comportamentos executados, ou seja, cada comportamento apresentou uma amplitude característica. Desse modo, a vibração nas folhas provavelmente pode auxiliar na eficiência dessas formigas durante o processamento do material vegetal para a incorporação no seu simbionte.

Palavras-Chave: Comportamento; Bioacústica; Eucalyptus sp; Formigas cortadeiras.

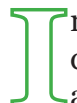
n Formicidae there are two ways of producing sounds: drumming different parts of the body against the substrate and stridulation (HöLLDOBLER \& WILSON 1990). Stridulation refers to the production of vibrational signals that result from rubbing a cuticular ridge on a part of the body above a dentate ridge (AKAY 2002). This process occurs by rubbing the plectrum (a cuticular protrusion found on the tergit of the third abdominal segment) on the pars stridens (the set of parallel striae found on the fourth abdominal segment, i.e., the gaster) (MARKL 1965; HILL 2009). Several functions of stridulation have been described in ants, including alarm signaling, recruitment communication and the coordination of activities performed inside the nest such as excavation, change of place and foraging (HICKLING \& BROwN
2000; Rauth \& Vinson 2006; Mercier et al. 2007; Menzel \& MARQUESS 2008).

MARKL (1973) proposed that the stridulatory organ emerged to help with nest building and to rescue buried workers and that it is therefore important for ground nesting species. Based on this proposal, Golden \& Hill (2016) verified the hypothesis raised by HÖLLDOBLER \& WiLSON (1990) that ant species that form subterranean nests stridulate more than those that build nests on trees. The authors compared the presence or absence of this organ between arboreal and terrestrial species and observed a higher frequency in the former. Thus, stridulation did not
Edited by:

William Costa Rodrigues

\section{Article History:}

Received: 31.vii.2017

Accepted: 09.iv.2018
Corresponding author:

Amanda Aparecida Carlos

७amandacarlos@yahoo.com.br

(3) http://orcid.org/0000-0002-6583-3287
Funding agencies:

$\triangle$ Fundação de Amparo à Pesquisa do Estado de São Paulo (FAPESP) 
evolve first as an alert function during excavation and burial of nestmates (GOLDEN \& HILL 2016).

In leaf-cutting ants, investigators described these sound signals during foraging for worker recruitment, either to communicate sources of attractive plant substrates or to alert to danger, and during nest excavation (Roces 1993; TAUTZ et al. 1995; Roces \& Hölldobler 1995; Roces \& Hölldobler 1996; Pielström \& Roces 2012). RocEs \& HÖLLDOBLER (1996) observed that, in leaf-cutting ants, stridulation is an important mechanism of short-range recruitment of workers to collect adequate plant material, i.e., depending on the quality of leaves, other workers are recruited in their direction through vibration. This signal is potentiated when pheromones are released on the trail (HÖLLDOBLER \& RocES 2001).

Data regarding the reception of signals by workers are contradictory. According to RocEs \& TAUTZ (2001), vibrational signals are transmitted through the substrate and detected by the worker's legs, but there may also be modified hairs that help capture these signals. On the other hand, HickLING \& BRown (2000) suggested transmission to occur through the air and the receptors are the sensilla trichodea (antennae).

Atta vollenweideri Forel exhibits a collective behavior in which workers stridulate to recruit other workers for tunnel opening. The signals will then gradually decrease as the tunnels are opened (PIELSTRÖM \& ROCES 2012).

Another behavior associated with stridulation is that this signal helps when the forager provides a ride to its nestmate. This occurs at the time when the foragers adjust the leaves to return to the nest with the plant material. This is used to recruit minim workers that ride on these castes; functionally, one gives a ride and the other protects it against phorid parasitoids during the journey along the trails (ROCES \& HöLLDOBLER 1995).

Assuming that in Atta the reception of vibrational signals occurs through the substrate (ROCES \& HöLLDOBLER 1996) and considering the importance of stridulation during foraging, as well as the importance of preparation and incorporation of plant material and the behaviours involved, we propose the following questions: Do workers stridulate at the time when they process the plant substrate for incorporation into the symbiotic fungus garden?

\section{MATERIAL AND METHODS}

The experiment was conducted at Centro de Estudos de Insetos Sociais (CEIS), Instituto de Biociências, UNESP, Rio Claro, Brazil. A subcolony of Atta laevigata (Smith) (approximately $0.3 \mathrm{~mL}$ of fungus, workers and brood present in this portion), housed in a clear acrylic box (30 x $20 \mathrm{~cm})$, was used.

Two Eucalyptus sp. leaves were offered to the workers and vibrations of the substrate during plant processing in the symbiotic fungus (period comprising the cutting of the plant material to its incorporation) were recorded at intervals of 10 minutes. During these recordings, the sound parameters were measured, the number of workers in the plant fragment was quantified, and the behavioural tasks performed were observed as described by ANDRADE et al. (2002): cutting, licking, shredding and crimping the leaves.

In the present study, vibration was recorded on leaves, but these signals were generated by the stridulation of workers. The sound to describe the vibration of the leaves of Eucalyptus sp. generated by the workers of Atta laevigata during processing and incorporation of the plant material into the symbiotic fungus, were recorded with a laser vibrometer (model PDV 100 Polytec) in the frequency range of 400 to $1,400 \mathrm{~Hz}$ (measured in Hertz) as established in previous tests. Thus, the laser was directed at the substrate while the workers prepared it for incorporation into the fungus. The observations lasted $12.8 \mathrm{sec}$ and the vibration patterns were recorded in pdv, transformed into "sound track" (.wav), and analyzed with the VIBSoFt 4.6 and RAVEN 1.4 software.

The variables generally measured in ants are the frequency and duration of chirps (a set or sequence of pulses) and interchirp intervals (KERMARREC 1976; MARKL 1965, 1967, 1968; FERREIRA et al. 2010). The following measures were evaluated in the present study: the duration of chirps [milliseconds (ms)] and the number of chirps per second, dominant frequency [Hertz $(\mathrm{Hz})]$, and peak amplitude [waveform, the greater of the absolute values of Maximal Amplitude and Minimal Amplitude (u)] (RAven 1.4 software). The peak amplitude variable was added since studies have shown a clear variation in the oscillograms depending on the behaviour observed. The measures are based on the authors above, however the measurements are distinct due to the equipment being different.

Several temporal variables were also measured from the oscillogram: the pulse a and b duration $\left(\Delta t_{\mathrm{a}}\right.$ and $\left.\Delta \mathrm{t}_{\mathrm{b}}, \mathrm{s}\right)$, the chirp rate $\left(\mathrm{CR}, \mathrm{s}^{-1}\right.$; calculated as $1 / \mathrm{t} \operatorname{start}(\mathrm{x})-\mathrm{t} \operatorname{sart}(\mathrm{x}+1)$ ), the pause between pulse $a$ and $b$ and between the end of pulse $b$ and the beginning of the next chirp.

The experiment lasted for $2 \mathrm{~h}$ and $20 \mathrm{~min}$, corresponding to the time necessary for the cutting and incorporation of the leaves offered. The vibrational signals were recorded at intervals of $10 \mathrm{~min}$, totaling 15 records of $12.8 \mathrm{sec}$ each (Table 1 ). This time was sufficient for the initiation of leaf incorporation into the symbiotic fungus.

\section{RESULTS AND DISCUSSION}

The main frequency of vibration produced by workers in the leaves ranged from 516.88 to $1,205.9 \mathrm{~Hz}$. These data were independent of the behavioural task or number of ants. Wide oscillations were observed in the records, except for the recording of the shredding task which was constant over the 12.8 sec analyzed (Table 1).

In the record obtained 80 min after the leaf fragment had been offered, one worker was cutting the substrate, while the other two workers were immobile on the substrate and therefore produced no movement that could directly affect the vibrational analysis.

Another parameter analyzed was the peak amplitude, which also showed wide oscillation in the behavioural repertoire analyzed (Table 2; Figure 1). This parameter was not characteristic for the behaviours. However, in the licking task, this parameter differed in the first analysis compared to the other recordings of this behaviour (Figure 2).

This study demonstrated different vibrations in the substrate according to the behavioural task executed by the workers, with the observation of different amplitudes in a certain behaviour (Figure 1). The act of licking in recorded times was the most frequent compared to the other behaviors and occurred in all observations, presenting the same amplitude, except in $10 \mathrm{~min}$ when the amplitude was higher, probably due to the greater effort in the execution of this task by the ants (Figure 2).

At the beginning of processing, the ants started to lick the leaves. The licking task has been associated with asepsis of the plant substrate, removing impurities and the epicuticular wax layer (Diniz \& Bueno 2009). Consequently, the workers spent more energy with this task to avoid contamination of the symbiotic fungus and to humidify the leaf, facilitating its preparation for incorporation (GARRETT et al. 2016). 
Table 1. Duration and number of chirps per second recorded in the plant substrate during processing of Eucalyptus sp. leaves by Atta laevigata.

\begin{tabular}{|c|c|c|c|c|}
\hline Record (minutes) & Behaviour & Number of ants & $\begin{array}{l}\text { Duration of chirps } \\
{[\mathrm{ms}](\text { Mean } \pm \text { SD) }}\end{array}$ & $\begin{array}{c}\text { Number of chirps/ } \\
\text { second }^{*}\end{array}$ \\
\hline 10 & Licking & 4 & $16.80 \pm 10.26$ & $16-27$ \\
\hline 20 & Licking & 3 & $14.69 \pm 8.53$ & $1-22$ \\
\hline 30 & Licking & 3 & $14.28 \pm 7.70$ & $1-7$ \\
\hline 40 & Licking & 3 & $14.45 \pm 7.47$ & $6-17$ \\
\hline 50 & Licking & 4 & $11.41 \pm 3.84$ & $1-17$ \\
\hline 60 & Licking & 3 & $12.07 \pm 4.25$ & $4-18$ \\
\hline 70 & Licking & 5 & $13.64 \pm 6.54$ & $1-9$ \\
\hline 80 & Cutting & 1 & $11.35 \pm 2.83$ & $1-18$ \\
\hline 90 & Licking & 3 & $10.97 \pm 3.74$ & $1-7$ \\
\hline \multirow{2}{*}{100} & Licking & 3 & \multirow{2}{*}{$11.32 \pm 3.47$} & \multirow{2}{*}{$1-13$} \\
\hline & Crimping & 1 & & \\
\hline 110 & Licking & 3 & $12.29 \pm 5.54$ & $2-9$ \\
\hline 120 & Licking & 2 & $13.81 \pm 7.57$ & $1-9$ \\
\hline 130 & Shredding & 2 & $14.25 \pm 1.50$ & $4-13$ \\
\hline 140 & Shredding & 3 & $13.34 \pm 6.03$ & $1-3$ \\
\hline 150 & Licking & 4 & $13.09 \pm 5.36$ & $1-9$ \\
\hline
\end{tabular}

*Variation in the number of chirps produced during vibration of the substrate over 12.8 seconds per sample analyzed.

Table 2. Dominant frequency and peak amplitude recorded in Eucalyptus sp. leaves during processing by Atta laevigata for incorporation into the symbiotic fungus.

\begin{tabular}{|c|c|c|c|c|c|}
\hline Record (minutes) & Behaviour & $\begin{array}{c}\text { Number of ants on } \\
\text { the leaf fragment }\end{array}$ & $\begin{array}{l}\text { Range of peak } \\
\text { amplitude }[u]^{*}\end{array}$ & $\begin{array}{c}\text { Mean peak } \\
\text { amplitude }[u] \\
(\text { Mean } \pm \text { SD) }\end{array}$ & $\begin{array}{c}\text { Dominant } \\
\text { frequency }[\mathrm{Hz}] \\
(\text { Mean } \pm \text { SD })\end{array}$ \\
\hline 10 & Licking & 4 & $298-1351.4$ & $599.55 \pm 216.45$ & $864.98 \pm 146.46$ \\
\hline 20 & Licking & 3 & $15.2-63.5$ & $34.58 \pm 11.50$ & $749.28 \pm 184.82$ \\
\hline 30 & Licking & 3 & $14.6-78.3$ & $36.16 \pm 13.09$ & $706.89 \pm 161.75$ \\
\hline 40 & Licking & 3 & $22.8-110.6$ & $43 \cdot 38 \pm 15 \cdot 76$ & $808.70 \pm 170.57$ \\
\hline 50 & Licking & 4 & $21.6-65.8$ & $39.95 \pm 10.42$ & $818.89 \pm 173.28$ \\
\hline 60 & Licking & 3 & $18.9-62.60$ & $37.51 \pm 11.92$ & $636.78 \pm 174.67$ \\
\hline 70 & Licking & 5 & $25-100.1$ & $50.09 \pm 16.40$ & $654.26 \pm 159.16$ \\
\hline 80 & Cutting & 1 & $15.5-56.9$ & $32.53 \pm 10.90$ & $716.85 \pm 178.44$ \\
\hline 90 & Licking & 3 & $19.5-51.6$ & $32.31 \pm 7.70$ & $857.70 \pm 148.60$ \\
\hline \multirow{2}{*}{100} & Licking & 3 & \multirow{2}{*}{$17.4-37.7$} & \multirow{2}{*}{$24.13 \pm 4.91$} & \multirow{2}{*}{$869.94 \pm 160.60$} \\
\hline & Crimping & 1 & & & \\
\hline 110 & Licking & 3 & $23.3-47.2$ & $31.76 \pm 6.88$ & $810.67 \pm 150.10$ \\
\hline 120 & Licking & 2 & $22.7-97.1$ & $46.09 \pm 15.33$ & $762.41 \pm 167.62$ \\
\hline 130 & Shredding & 2 & $13.5-16.8$ & $15.48 \pm 1.45$ & $516.80 \pm 0.00$ \\
\hline 140 & Shredding & 3 & $21-91.5$ & $41.42 \pm 16.69$ & $868.22 \pm 143 \cdot 32$ \\
\hline 150 & Licking & 4 & $18-67.8$ & $35.68 \pm 12.68$ & $879.79 \pm 141.96$ \\
\hline
\end{tabular}

*Range of peak amplitude for each chirp described.

The greatest range of peak amplitude described for each chirp was observed in the first evaluation. However, the mean dominant frequency ranged from 516.80 to $879.79 \mathrm{~Hz}$ between behaviours (Table 2). Chirps consist of a long series of repetitive pulses and each pulse results from the stridulatory organ of workers.

The duration of chirps was also slightly longer in the first recording (16.80 ms), with four workers licking the leaf. This variable was shorter in the subsequent recordings, but remained constant. This finding can be explained by the fact that chirp duration is a characteristic of the species and, like frequency, can be used for species identification. Thus, both variables exhibited a pattern and did not differ (FERREIRA et al. 2010). Although the dominant frequency showed a wide oscillation within one analysis, it always varied within a range common to all recordings, so being a parameter used to differentiate species.

Stridulation is also used during foraging as a recruitment signal of workers to an adequate plant source so that the material is cut and transported to the colony (HÖLLDOBLER \& ROCES 2001). Probably, when the substrate was offered to the colony, which received greater attention, the effort of the ant to perform the task resulted in greater peak amplitudes, corresponding to a higher signal intensity. In contrast, the dominant frequencies recorded on the leaves that were practically constant may have contributed to the fact that the number of individuals remained constant on the leaves since, as mentioned earlier, the number of individuals continued the same as the leaves were cut into fragments. 

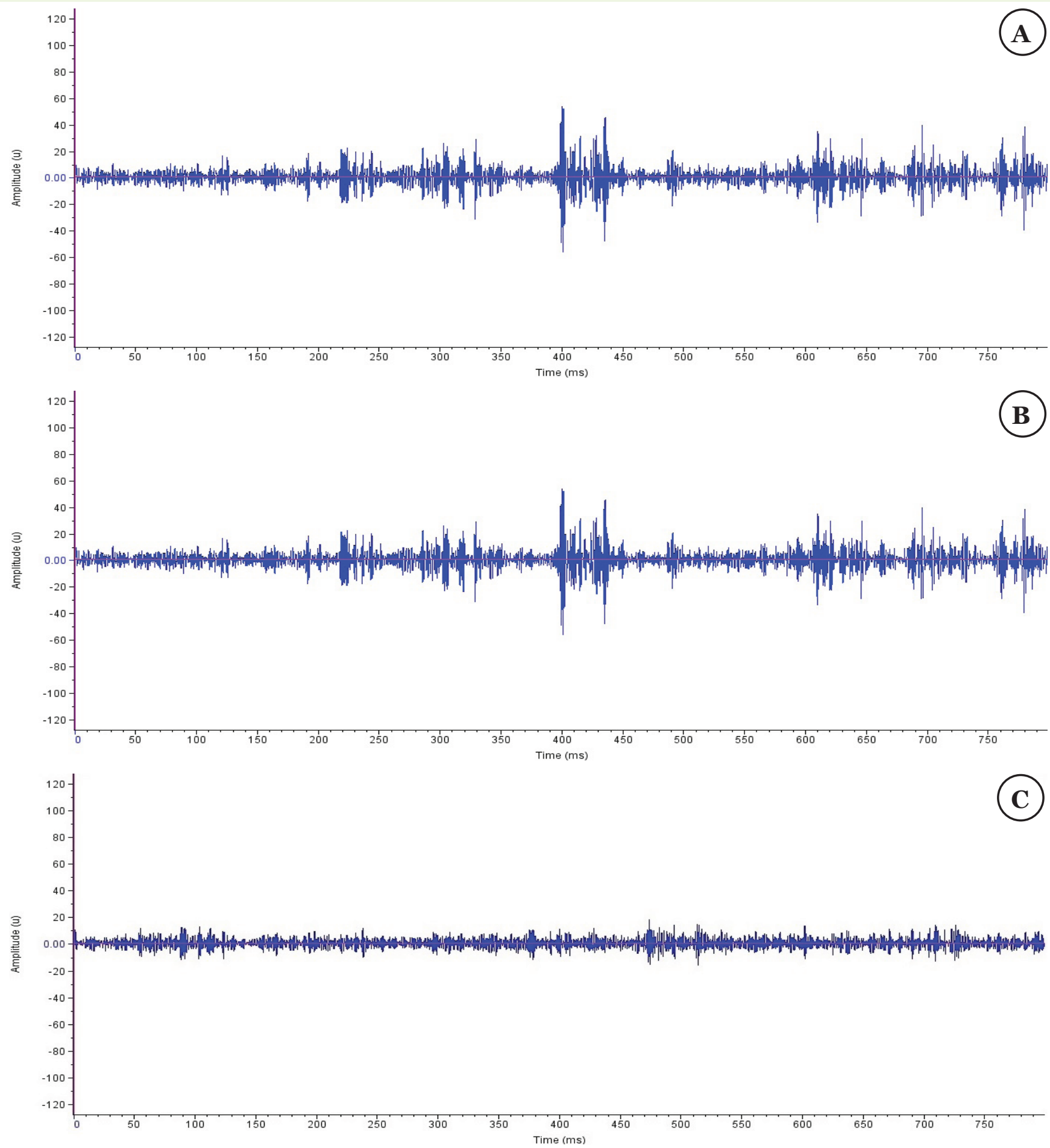

Figure 1. Oscillogram $(0.8 \mathrm{sec})$ of stridulatory vibrations produced by Atta laevigata workers in Eucalyptus leaves during processing of the plant material. A. Three workers licking the leaf ( $40 \mathrm{~min}$ after the leaf had been offered). B. One worker cutting the leaf ( 80 minutes after the leaf had been offered). C. Two workers shredding the leaf (130 minutes after the leaf had been offered).

This was also observed in the present study on A. laevigata which the number of workers remained practically the same during substrate processing, ranging from 2 to 4 ants across the observations, even when the fragments decreased in size. However, there was only one worker performing the task of leaf cutting. These results suggest that vibration in the substrate contributed to the fact that the workers remained during substrate processing inside the colony. However, this is only a hypothesis since we did not mark which workers were present since the beginning of processing and how many were recruited and/or stayed in place to give continuity to the process, a fact that needs to be clarified.

Regarding substrate processing, the number of chirps emitted was higher at the beginning when compared to the other observations. However, workers did not stop stridulating during leaf fragmentation and the number of ants thus remained constant during processing. It could therefore be observed during the experiment that the number of chirps per second decreased when the substrate was already fragmented. In addition, Roces et al. (1993) reported a signal repetition rate of 2 to 20 chirps/ second for Atta cephalotes (L.) and in the present study was of 2 to 21 chirps/sec for A. laevigata.

With respect to the behavioural tasks, licking was the most frequent task; however, this is a defined behavioural task in which workers spend more time executing it (LitTLEDyke \& Cherrett 1976; ANdrade et al. 2002; CARLOS et al. 2010). In contrast, crimping was analyzed but, since it was being executed together with other workers that were licking, it was not possible to perform a separate oscillogram for it.

The present study showed variations in the vibratory signals emitted by the stridulation of the workers of A. laevigata in 

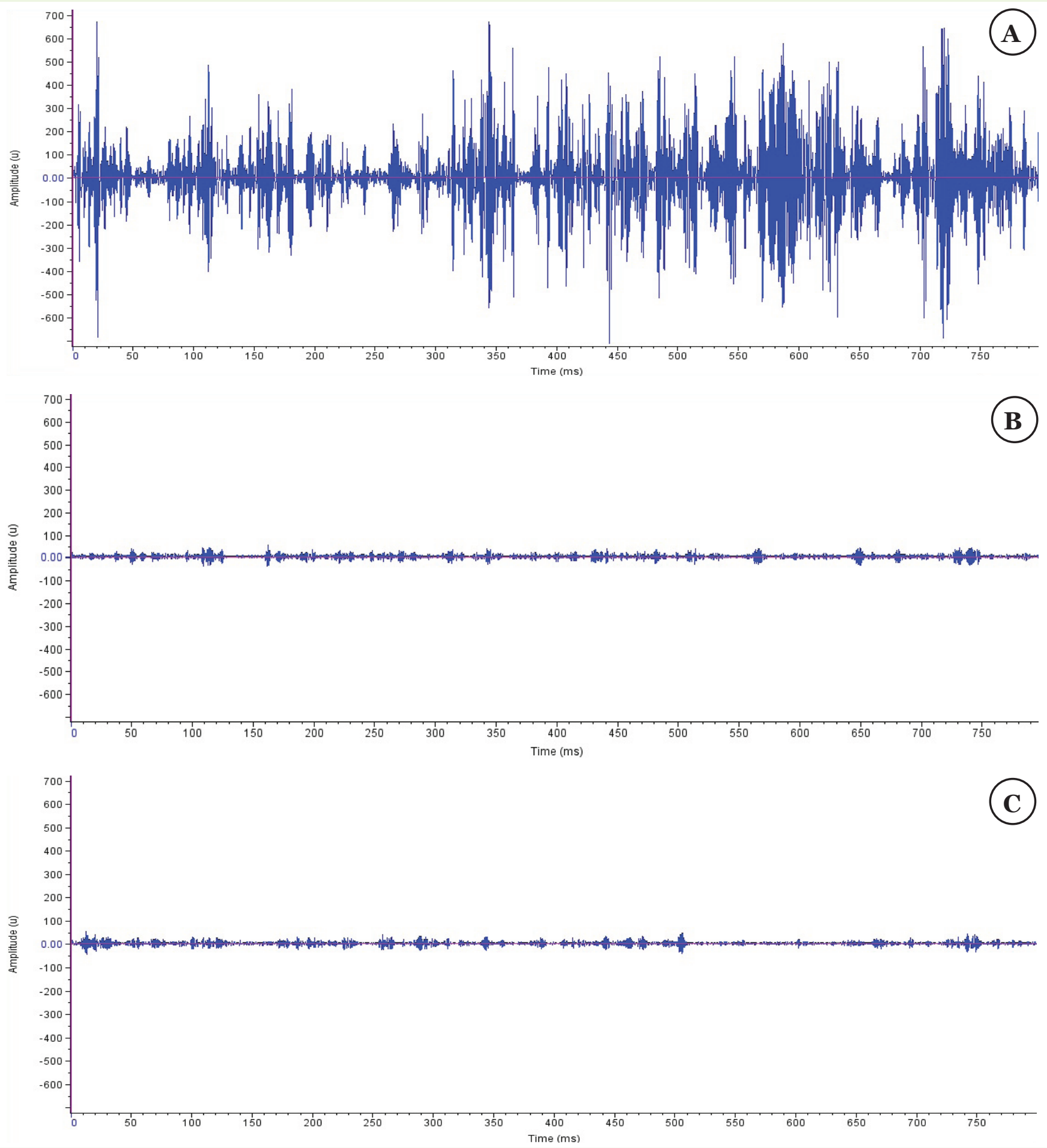

Figure 2. Oscillogram (0.7 seconds) of stridulatory vibrations produced while four Atta laevigata workers licked Eucalyptus leaves during preparation of this material for incorporation into the symbiotic fungus. A. After 10 minutes of leaf manipulation. B. After 60 minutes of leaf manipulation; C. After 150 minutes of leaf manipulation.

the execution of the behavioral tasks during the processing and incorporation of the Eucalyptus leaves in the fungus garden. Thus, the workers seem to compose a characteristic vibration for each behavior performed. It is suggested that the vibration in the substrate probably can aid in the efficiency of these ants during the processing of the vegetal material.

\section{ACKNOWLEDGEMENTS}

A.A. Carlos is grateful to Fundação de Amparo à Pesquisa do Estado de São Paulo (FAPESP) for financial support and the fellowship granted [grant numbers: 2009/17793-8 and 2014/06901-2].

\section{REFERENCES}

Akay, A., 2002. Acoustics of friction. Journal of the Acoustical Society of America, 111: 1525-1548. DOI: https://doi.org/10.1121/1.1456514.

Andrade, A.P.P., L.C. Forti, A.A. Moreira, M.A.C. Boaretto, V.M. Ramos \& C.A.O. Mattos, 2002. Behavior of Atta sexdens rubropilosa (Hymenoptera: Formicidae) workers during the preparation of the leaf substrate for symbiont fungus culture. Sociobiology, 40: 293-306.

Carlos, A.A., A.S. Rodrigues, L.C. Forti, M.M. Passador \& J. Sierra, 2010. Behavioral response of the leafcutter ant Atta sexdens rubropilosa (Hymenoptera, Formicidae), to components of citrus pulp. Sociobiology, 55: 1-10.

Diniz, E.A. \& O.C. Bueno, 2009. Substrate preparation behaviors for the cultivation of the symbiotic fungus in leaf-cutting ants of the genus Atta (Hymenoptera: Formicidae). Sociobiology, 53: 651-666. 
Ferreira, R., C. Poteaux, J.H.C. Delabie, D. Fresneau \& F. Rybak, 2010. Stridulation reveal cryptic speciation in Neotropical sympatric ants. Plos ONE, 5: 1-11. DOI: https://doi.org/10.1371/journal.pone.0015363.

Garrett, R.W., K.A. Carlson, M.S. Goggans, M.H. Nesson, C.A. Shepard \& R.M.S. Schofield, 2016. Leaf processing behaviour in Atta leafcutter ants: $90 \%$ of leaf cutting takes place inside the nest, and ants select pieces that require less cutting. Royal Society Open Science, 3: 150111. DOI: https://doi.org/10.1098/rsos.150111.

Golden, T.M.J. \& P.S.M. Hill, 2016. The evolution of stridulatory communication in ants, revisited. Insectes Sociaux, 63: 309319. DOI: https://doi.org/10.1007/s00040-016-0470-6.

Kermarrec, A., H. Mauleon, \& A. Abud Antun, 1976. La stridulation de Acromyrmex octospinosus Reich. (Hymenoptera: Formicidae): Biométrie de l'appareil stridulateur et analyse du signal produit. Insectes Sociaux, 23: 29-48. DOI: https://doi.org/10.1007/bfo2283904.

Hickling, R. \& R.L. Brown, 2000. Analysis of acoustic communication by ants. Journal of the Acoustics Society of America 108: 1920-1929. DOI: https://doi.org/10.1121/1.1290515.

Hill, P.S.M., 2009. How do animals use substrate-borne vibrations as an information source? Naturwissenschaften, 96: 1355-1371.

Hölldobler, B \& E.O. Wilson, 1990. The ants. Cambrigde: Harvard University Press, 746 p.

Hölldobler, B. \& F. Roces, 2001. The behavioral ecology of stridulatory communication in leaf-cutting ants, p. 92109. In: Dugatkin, L.A. (Ed.). Model systems in behavioral ecology - Integrating conceptual, theoretical and empirical approaches. Princeton: Princeton University Press, 576 p.

Littledyke, M. \& J.M. Cherrett, 1978. Olfactory responses of the leaf-cutting ants A. cephalotes L) and Acromyrmex octospinosus (Reich.) (Hymenoptera: Formicidae) in the laboratory. Bulletin of Entomological Research, 68: 273-282. DOI: https://doi.org/10.1017/s0007485300007355.

Markl,H.,1965. Stridulationinleafcutting ants. Science, 149:13921393. DOI: https://doi.org/10.1126/science.149.3690.1392.

Markl, H., 1967. Die Verständigung durch Stridulationssignale bei Blattschneiderameisen I. Die biologische Bedeutung der Stridulation. Zeitschrift fur vergleichende Physiologie, 57: 299-330. DOI: https://doi.org/10.1007/bfo0303001.

Markl, H., 1968. Die Verständigung durch Stridulationssignale bei Blattschneiderameisen II. Erzeugung und Eigenschaften der Signale. Zeitschrift fur vergleichende Physiologie, 60: 103-150. DOI: https://doi.org/10.1007/bfoo878447.

Markl, H., 1973. The evolution of stridulatory communication in ants. In: Proceedings of the VII Congress IUSSI, London, p. 258-265.
Menzel, T.O. \& J.R. Marquess, 2008. The substrate vibration generating behavior of Aphaenogaster carolinensis (Hymenoptera: Formicidae). Journal Insect Behaviour, 21: 82-88. DOI: https://doi.org/10.1007/s10905-007-9109-9.

Mercier, J.L., 2007. Hammering, mauling, and kissing: stereotyped courtship behavior in Cardiocondyla ants. Insectes Sociaux, 54: 403-411. DOI: https://doi.org/10.1007/ s00040-007-0960-7.

Pielström, S. \& F. Roces, 2012. Vibrational communication in the spatial organization of collective digging in the leaf-cutting ant Atta vollenweideri. Animal Behaviour, 84: 713-752. DOI: https://doi.org/10.1016/j.anbehav.2012.07.008.

Rauth, S.J. \& S.B. Vinson, 2006. Colony wide behavioral contexts of stridulation in imported fire ants (Solenopsis invicta Buren). Journal of Insect Behavior, 19: 293-304. DOI: https://doi.org/10.1007/s10905-006-9026-3.

Raven PRO. Version 1.4, 2011. Bioacoustics Research Program. Raven Pro: Interaction Sound Analysis software (Version 1.4) (Computer Software). Ithaca, NY: The Cornell Laboratory of Ornithology. Available on: <http://www.birds.cornell.edu/ raven $>$.

Roces, F., J. Tautz \& B. Hölldobler, 1993. Stridulation in leaf cutting ants: short-range recruitment through plant borne vibrations. Naturwissenschaften, 80: 521-524. DOI: https://doi.org/10.1007/bfo1140810.

Roces, F. \& B. Hölldobler, 1995. Vibrational communication between hitchhikers and foragers in leaf cutting ants (Atta cephalotes). Behavioral Ecology and Sociobiology, 37: 297302. DOI: https://doi.org/10.1007/s002650050194.

Roces, F. \& B. Hölldobler, 1996. Use of stridulation in foraging leaf cutting ants: mechanical support during cutting or short-range recruitment signal? Behavioral Ecology and Sociobiology, 39: 293-299. DOI: https://doi.org/10.1007/ s002650050292.

Roces, F. \& J. Tautz, 2001. Ants are deaf. Journal of the Acoustical Society of America, 109: 3080-3082. DOI: https://doi.org/10.1121/1.1370085.

Roces, F., 1993. Both evaluation of resource quality and speed of recruited leaf-cutting ants (Acromyrmex lundi) depend on their motivational state. Behaviour Ecology and Sociobiology, 33: 183-189. DOI: https://doi.org/10.1007/bfoo216599.

Tautz, J., F. Roces \& B. Holldobler, 1995. Use of a sound based vibratome by leaf cutting ants. Science, 267: 84-87. DOI: https://doi.org/10.1126/science.267.5194.84.

Vibsoft 4.7, 1997-2009. Polytec Vibrometer Software, Polytec $\mathrm{GmbH}$, Waldbronn.

\section{Suggestion citation:}

Carlos, A.A., E.A. Diniz, S.V. da Silva \& O.C. Bueno, 2018. Vibration of the plant substrate generated by workers' stridulation during fungus garden cultivation in Atta laevigata (Smith) (Hymenoptera: Formicidae). EntomoBrasilis, 11 (2): 107-112.

Available on: doi:10.12741/ebrasilis.v11i2.732
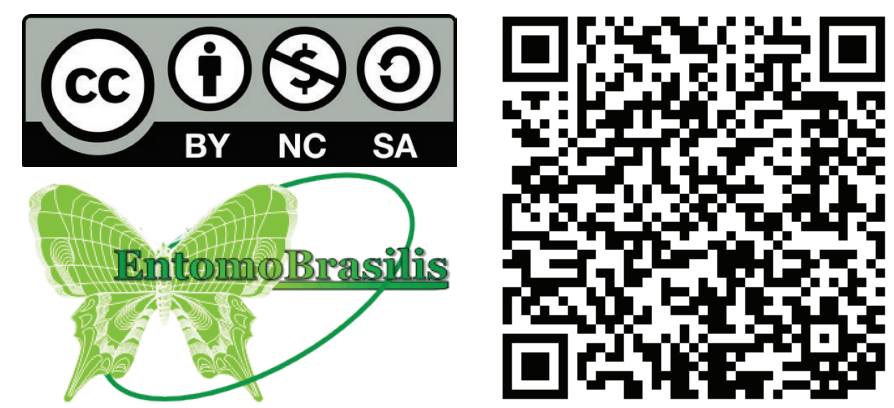